\title{
Lean Thinking in Banking Industry: Waste Identification on Credit Disbursement Process
}

\author{
Indah Rizkya ${ }^{1, *}$, Khalida Syahputri ${ }^{1}$, Rahmi M Sari ${ }^{1}$, Ikhsan Siregar ${ }^{1}$ \\ ${ }^{1}$ Department of Industrial Engineering, Faculty of Engineering, Universitas Sumatera Utara, Medan - Indonesia
}

\begin{abstract}
Waste is not only found in the manufacturing industry but also in the service industry, especially in banking industry. This paper describes a comprehensive lean approach applied to the banking industry. Lean in banking industry is used to find waste along the flow of value. This paper focuses on finding waste in consumer loan disbursement process by classifying consumer credit loan activity into value added activity, necessary but non value added activity, and waste. Process Activity Mapping is used to describe all activities in consumer credit disbursement waste identification. The identification shows that total time of consumer credit disbursement activities is 7,461 minutes equal to 15,54 days. This means the average time required to complete the consumer credit process starts from the documents receipt to the disbursement of credit is 15,54 working days. Failure Mode and Effect Analysis (FMEA) is used to decide the level of factor causing waste. The results of FMEA shows the length of time required for consumer loan disbursement due to verification repetition process and waiting time of documents to processed.
\end{abstract}

Keywords: Credit Disbursement Process, FMEA, Lean Banking

\section{Introduction}

The high growth of banking industry causes the competition increasingly in the fight over consumers. Banking industry is required to be more innovative in viewing market conditions to provide services to consumers. On the other hand, the growth of consumptive consumer needs causes banking industry become interested in consumer credit or consumer loans.

The problem happens in this research is consumer dissatisfaction toward service performance of bank. Debtors feel the requirements of credit management consumer convoluted, data verification done repeatedly resulting in the length of time should be awaited prospective debtor to know the outcome of credit decision. As a result, the process of termination and disbursement process of credit exceeds Standard Level Agreement (SLA) which is determined by the bank. Debtors dissatisfaction with bank services resulted in the withdrawal of processed documents, resulting in wasted time without the outcome of credit decision. Consumer credit loan activities need to be analyzed to see how they affects the effectiveness of business processes.

Lean concepts can be used to review business processes in the company and its activities. The key concepts, the practices, organizational tools and techniques that are known as lean thinking and how to develop, maintain, and improve the business on a sustainable and long term basis [1]. Lean concentrates on the stabilization and standardization of work processes and critical issues can be solved with complete and feasible and develop the ability of the workforce to think critically, solve problems and improve work flow [2].

Lean application form in the manufacturing industry can be used in the service industry, known as lean service. Both of lean service and lean manufacturing has the same concept, such as increasing activities that provide added value to products, eliminating waste that occurs in the service process and creating a value stream mapping. The implementation of lean consept in services industries is needed to reduce the operational costs, the processing time, and to increase the flexibility of industry. Flexibility allows the industry to adapt more quickly to customer needs. Lean has been successfully implemented in many non-manufacturing sectors, such as hospitals, transportation, education, government, administration, financial institutions, insurance and health [3]. A lean approach can be used in the service sector is lean service [4]. Lean thinking includes understanding the philosophy of constantly looking for ways to waste reduction as continuous improvement to using lean tools and techniques to increase the customer satisfaction [5].

Previous studies on the lean approach has been made. Staats et al. lean approach has been applied to Indian software services firm [6]. Asnan et al. that observed how government agencies adopted and implemented lean management to improve efficiency and provide quality of services to their customers [7]. Barraza et al. applies lean concepts to local public service providers councils in specific Spanish contexts [8]. However, previous

* Corresponding author: indahrizkya@usu.ac.id 
researches in problems handling with lean approach has not been done in banking industry especially in Indonesia. This study aims to identify the waste occurs in the consumer credit service process affects the effectiveness of business processes.

\section{Methodology}

Research conducted in one of the banking company in Indonesia where the object of this study in the form service process of prospective debtor. Research begins with observation to observe the condition occurs in the bank. After that, determined the purpose of research as a solution in problems handling. Then performed data processing to get the set goals. Data collected to perform data processing in the process form of consumer credit loan service and processing time at each activity of consumer credit. Lean banking is used to find the waste occurs in consumer credit loan activities.

Lean thinking describe the philosophy of a managerial for increasing the value in customer perceived, through the addition of features to products and services and continuing to remove non-value-added activities such as waste [9]. The research stages with lean approach begins with identifying the consumer flow of credit distribution process. Based on the flow of distribution process, will be obtained the processing time at each activity occurs during the consumer loan process. The next step is to recognize the waste occurs in the flow of process. Waste identification is carried out by clearly describing all activities that accurs along the production process into value added, necessary but non value added, and non value added activities [10].

The activities description in consumer flow of loan process done by using Process Activity Mapping. Process Activity Mapping (PAM) is a key tool to detailed mapping of customers order fulfillment process. In a wider scope, PAM is used to recognize the lead time and productivity opportunities for both the flow of physical product and information. PAM not only used in the shop floor but also in other areas of supply chain [11]. With the result of mapping process flow using process activity mapping, obatined activities belong to value added activities, necessary but non value added activities, and non value added activities. After the category at each activity is obtained, then do branstorming to describe the causes of occurrence to these problems become the input in making of fishbone diagram.

The problem occurs will be broken down into several categories such as human relationships, management, environment, methods, and tools/ equipment. Problem solving and root causes of the problem will be depicted in fishbone diagram by entering brainstroming sessions in determining the causes of problem from each cause category. From the results of fishbone diagram, identify the causes of significant waste by using Failure Mode and Effect Analysis (FMEA). FMEA approach used to recognize the potential risk factors. Failure Mode and Effect Analysis (FMEA) is used to decide the level of factor causing waste occurs in distribution of consumer credit loan.

\section{Result and Discussion}

\subsection{Process Activity Mapping}

Process activity mapping is used to describe the activities occurs from the application of credit from prospective debtor to credit disbursement. These activities will be categorized into value added activities, necessary but non value added activities, and non value added activities. The depiction of the consumer credit process flow can be seen in Figure 1.

The picture in figure 1 shows that waste occurs during the process of loan disbursement time consumer required during the disbursement process takes a long time. Waste occurs, among others, the activities performed in some departments such as document repetition verification activities performed by Sales Person, Account Sales Officer (AO Sales) and administration. In addition, the length of process time in some departments such as checking time caused long time of waiting time to obtain the checking results. As a result to the whole process of credit disbursement consumer spent a long time. Tabel 1 shows the actual processing time of the consumer credit disbursement at each activity (as an Process Activity Mapping).

Table 1. Average Time of Consumer Credit Activity

\begin{tabular}{|c|c|c|}
\hline Activity & $\begin{array}{c}\text { Processing } \\
\text { Time } \\
\text { (minute) }\end{array}$ & $\begin{array}{l}\text { Delay Time } \\
\text { (minute) }\end{array}$ \\
\hline 1 & 57 & 36 \\
\hline 2 & 177 & 40 \\
\hline 3 & 19 & 100 \\
\hline 4 & 58 & 0 \\
\hline 5 & 207 & 0 \\
\hline 6 & 178 & 340 \\
\hline 7 & 26 & 115 \\
\hline 8 & 956 & 142 \\
\hline 9 & 57 & 87 \\
\hline 10 & 711 & 98 \\
\hline 11 & 174 & 72 \\
\hline 12 & 53 & 252 \\
\hline 13 & 110 & 231 \\
\hline 14 & 261 & 0 \\
\hline 15 & 482 & 28 \\
\hline 16 & 740 & 0 \\
\hline 17 & 903 & 60 \\
\hline 18 & 52 & 395 \\
\hline 19 & 87 & 112 \\
\hline 20 & 983 & 131 \\
\hline 21 & 92 & 20 \\
\hline 22 & 145 & 74 \\
\hline 23 & 184 & 0 \\
\hline 24 & 173 & 10 \\
\hline 25 & 576 & 0 \\
\hline Total & 7461 & 2343 \\
\hline
\end{tabular}




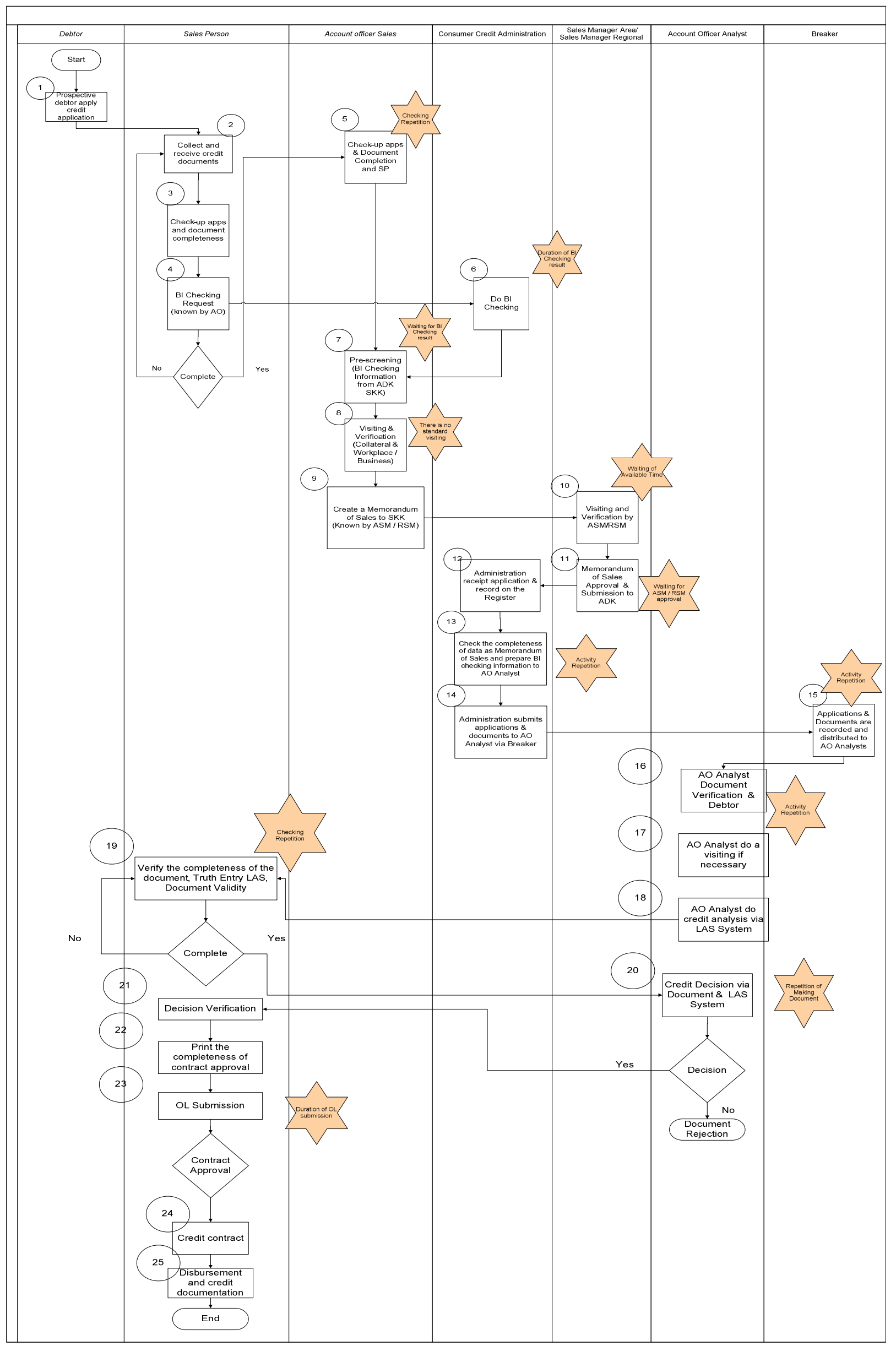

Figure 1. Process Activity Mapping of Credit Disbursement Consumer

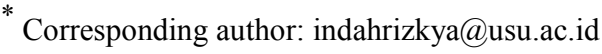


Based on the table 1, it can be found that with 25 activities total time of consumer credit implementation amounted to 7,461 minutes equal to 15,54 days, means to complete the process of consumer credit starting from the document receipt until the disbursement of credit takes an average time of 15.54 working days. This is due to the number of activities that are non value added activity such as waiting time (delay) in every activity performed.

\subsection{Brainstorming and Fishbone Diagram}

Brainstorming is done to describe the causes to the length of consumer loan disbursement process where at each category is described through the discussion with employees who understand the issues to be discussed. The results of branstorming will be depicted in the fishbone diagaram by exposing the problem and root causes of the problem in determining the cause at each category. Based on the results of brainstorming and fishbone diagram, it is found that the root causes of the problem occurs, among others, verification repetition, the absence of standard credit process, job description is unclear, miscommunication between departments, ability to analyze the feasibility of debtor candidate is low, limitation of Loan Approval System (LAS) system, Terms of credit difficult to prospective debitor, there is no standard procedure, there is no standard service, and document validity is low with type of waste in the form of duplication, unclear communication, lost oppurtunity, delay, and unnecessary movement.

\subsection{Failure Mode and Effect Analysis}

Failure Mode and Effect Analysis (FMEA) is an analysis performed to recognize activities provide opportunities of the greatest potential failure. The greatest potential failure is seen from the Risk Periority Number (RPN). Risk Priority Number (RPN) is obtained from the multiplication of severity, occurrence, and detection. Severity is the level of seriousness occurs due to failure mode. Occurance is a measure of how often a potential cause occurs. Detection is the level of accuracy of the detection tool used. Observations on credit disbursement activities, reviews of past corporate data, interviews and brainstorming with related banking managers are used as a basis for assessing severity, occurance, and detection. The FMEA 5 assessment is the worst and 1 is a worst score. The FMEA value recapitulation at each cause of the problem can be seen in Table 2 .

Based on the table 2, it is found that the length of loan disbursement has the highest RPN (Risk Priority Number) value in the repetitive data verification activity. Verification repetition activity is one of the waste duplication causes the credit disbursement process to be unappropriate SLA as well as causing the debtor complaint against the consumer credit service. To handle these problems, it is necessary to conduct training for employees especially to Sales Person (SP), Account Officer Sales (AO Sales) and administration department and standard operating procedure in conducting credit disbursement process and process implementation procedure becomes structured and clear. The results of this study supporting previous studies that lean thinking is able to identify the waste occurs especially in the banking industry $[3,5]$.

Table 2. Recapitulation of FMEA Value

\begin{tabular}{|c|c|c|c|c|}
\hline Problem & Severity & Occurance & $\begin{array}{c}\text { Detec } \\
\text { tion }\end{array}$ & $R P N$ \\
\hline $\begin{array}{l}\text { Repetition of } \\
\text { Verification }\end{array}$ & 4 & 5 & 5 & 100 \\
\hline $\begin{array}{l}\text { There is no } \\
\text { time limit on } \\
\text { document } \\
\text { process at } \\
\text { each section }\end{array}$ & 3 & 5 & 5 & 75 \\
\hline $\begin{array}{l}\text { There is no } \\
\text { standard credit } \\
\text { process }\end{array}$ & 5 & 3 & 5 & 75 \\
\hline $\begin{array}{l}\text { Miscommunic } \\
\text { ation Between } \\
\text { Departments }\end{array}$ & 3 & 4 & 5 & 60 \\
\hline $\begin{array}{l}\text { Unclear Job } \\
\text { description }\end{array}$ & 3 & 5 & 4 & 60 \\
\hline $\begin{array}{l}\text { Ability to } \\
\text { analyze the } \\
\text { feasibility of } \\
\text { prospective } \\
\text { debtor is low }\end{array}$ & 5 & 2 & 5 & 50 \\
\hline $\begin{array}{l}\text { Terms of } \\
\text { credit difficult } \\
\text { to prospective } \\
\text { customers }\end{array}$ & 4 & 4 & 3 & 48 \\
\hline $\begin{array}{l}\text { Limitation of } \\
\text { LAS access } \\
\text { system }\end{array}$ & 3 & 3 & 5 & 45 \\
\hline $\begin{array}{l}\text { There is no } \\
\text { standard } \\
\text { procedure }\end{array}$ & 3 & 3 & 4 & 36 \\
\hline $\begin{array}{l}\text { Knowledge of } \\
\text { the document } \\
\text { validity is low }\end{array}$ & 4 & 4 & 2 & 32 \\
\hline $\begin{array}{l}\text { There is no } \\
\text { standard } \\
\text { service }\end{array}$ & 3 & 3 & 3 & 27 \\
\hline
\end{tabular}

\section{Conclusion}

The length of time consumer loan disbursement is caused by the waste occurs during the disburse ment process such as duplication, unclear communication, error, lost oppurtunity, delay, and unnecessary movement which is the most dominant waste occurs is duplication with activity in the form of repetition verification done. This is due to unclear work procedures and employee ability to repeat the same process is low and standard operating procedure is needed for consumer loan disbursement and training for employees

\footnotetext{
*Corresponding author: indahrizkya@usu.ac.id
} 


\section{Acknowledgement}

This paper is financially supported by the Universitas Sumatra Utara for publication. Authors would like to thanks to one of the Indonesian banking industry for research permission.

\section{References}

1. V.A. Maria, Annals of The University of Craiova Economi Sciences, 39 (2011)

2. V. Vignesh, M. Suresh, and S. Aramvalarthan, IOP Conf. Series: Materials Science and Engineering, 149 (2016)

3. Z.F. Ikatrinasari, E.I. Hryanto, Journal of Service Science and Management, 7 (2014)

4. F. Abdi, S. Shavarini and S. Hoseini, Journal of Services Research 6, (2006)

5. J.J. Schiele, C.P. McCue, Journal of Public Procurement 11, 2 (2011)

6. B.R. Staats, D.J. Brunner, \& D.M Upton, Journal of Operations Management 29, 5 (2011)
7. R. Asnan, N. Nordin, \& S. N. Othman, Proceeding Social and Behavioral Sciences, 211 (2015)

8. M.F. Barraza, T. Smith, S.M. Dahlgaard-Park, The TQM Journal 21, 2 (2009)

9. A. Bonaccorsi, G. Carmignani, F. Zammori, Journal of Service Science and Management, 4 (2011)

10. K. Syahputri, R.M. Sari, I. Rizkya, and I. Siregar, IOP Conf. Series: Materials Science and Engineering, 180 (2017)

11. P. Hines, N. Rich, International Journal Operation and Production Management, 17 (1997)

12. R.K. Sharma, D. Kumar, and P. Kumar, International Journal of Quality \& Reliability Management 22, 9 (2005)

*Corresponding author: indahrizkya@usu.ac.id 